\title{
Classic Bartter syndrome complicated with profound growth hormone deficiency
}

\author{
Masanori Adachi ${ }^{1 *}$, Toshihiro Tajima², Koji Muroya', Yumi Asakura' \\ From 7th APPES Biennial Scientific Meeting \\ Nusa Dua, Bali. 14-17 November 2012
}

\section{Case history}

A Japanese boy was born at 41 weeks of gestational age by spontaneous cephalic delivery, with birth weight $3,680 \mathrm{~g}$. Family history was remarkable for his elderly sister suffering from classic Bartter syndrome. He also was diagnosed as classic Bartter syndrome, based on the findings such as failure to thrive, metabolic alkalosis with hypokalemia, and the activated renin-aldosterone system. The diagnosis was later confirmed by CLCNKB gene analysis which revealed compound heterozygous mutations: deletion of the exon 1 - 3 (derived from his mother) and $\Delta \mathrm{L} 130$ (derived from the father). Treatment with spironolactone, indomethacin, sodium chloride, and potassium supplementation was commenced at 8 months of age. However, his serum potassium level failed to normalize, and tended to be around $2-3 \mathrm{mEq} / \mathrm{L}$. He had mild intellectual impairment, and needed specialized education. When he was 11 years old, through the investigation for macrohematuria, renal stones with nephrocalcinosis were detected. This complication resolved following the amelioration of hypokalemia, which was achieved by vigorous potassium fortification. Because his growth rate was consistently subnormal and he was very short (-4.7SD), scrutiny for growth hormone (GH) secretion was conducted at his 14 years of age.

\section{Results}

Profound GH deficiency was evident. Serum IGF-1 level was $80 \mathrm{ng} / \mathrm{mL}$ (norm, 178-686), with IGFBP-3 $1.92 \mu \mathrm{g} / \mathrm{mL}$ (2.69-4.16). Pharmacologically stimulated GH levels were 0.15 and $0.39 \mathrm{ng} / \mathrm{mL}$, after insulin and arginine administration, respectively. His bone age was 11.4 years old (TW2-RUS for Japanese). MR imaging detected no abnormality within hypothalamic-pituitary region.

\section{Clinical course}

GH treatment with $0.15-0.19 \mathrm{mg} / \mathrm{kg} /$ week resulted in growth rate as much as $11.7 \mathrm{~cm}$ during the first 12-months, followed by $10.8 \mathrm{~cm}$ during the subsequent 12 months. Although his pubertal stage progressed from Tanner stage 1 to stage 2 during 2 years, $\Delta$ bone age / $\Delta$ chronological age was 1.02 . No significant change in serum potassium level was observed.

\section{Discussion}

In literature, GH deficiency in Bartter syndrome and Gitelman syndrome has been anecdotally reported, with diverse severity among patients. At present, its precise pathogenesis, as well as its prevalence, is unknown. Classic Bartter syndrome complicated with profound GH deficiency, as seen in this case, is rare. The sister of the case, who also suffered from classic Bartter syndrome, is $145 \mathrm{~cm}$ tall $(-2.0 \mathrm{SD})$ now and seemed not to be GH deficient. Her potassium level had been managed rather better than this case. It may be tempting to speculate that long-term hypokalemia may be harmful for somatotrophs to produce $\mathrm{GH}$.

\section{Authors' details \\ 'Kanagawa Children's Medical Center, Japan. ${ }^{2}$ Hokkaido University School of Medicine, Japan.}

Published: 3 October 2013

doi:10.1186/1687-9856-2013-S1-P40

Cite this article as: Adachi et al.: Classic Bartter syndrome complicated with profound growth hormone deficiency. International Journal of Pediatric Endocrinology 2013 2013(Suppl 1):P40.

${ }^{1}$ Kanagawa Children's Medical Center, Japan

Full list of author information is available at the end of the article

C 2013 Adachi et al; licensee BioMed Central Ltd. This is an Open Access article distributed under the terms of the Creative Commons 